\author{
S. Oumouss, G. Tobi, I. Rahmouni, H. Tahiri \& Y. El Bahloul
}

\title{
Phenotypic and cytogenetic diversity of local beet hybrids from Beta macrocarpa and $B$. vulgaris subsp. vulgaris crosses in Morocco
}

\begin{abstract}
Oumouss, S., Tobi, G., Rahmouni, I., Tahiri, H. \& El Bahloul, Y.: Phenotypic and cytogenetic diversity of local beet hybrids from Beta macrocarpa and B. vulgaris subsp. vulgaris crosses in Morocco. — Fl. Medit. 31: 207-222. 2021. — ISSN: 1120-4052 printed, 2240-4538 online.

Several barriers and challenges meet interspecific hybridization between taxa belonging to the genus Beta under Moroccan environmental conditions. Sugar beet (Beta vulgaris s. 1.), is a socioeconomically important recent crop, developed mainly for the sugar production in Morocco. B. macrocarpa, a beet wild relative, is characterized by a wide genetic richness and high adaptative capacity. Obtaining viable hybrids from crosses between these two taxa is challenging. Hence, we studied 75 beet hybrids harvested on two cultivated $(\mathrm{CH})$ and two wild (WH) parents separately. Twentyone effective agro-morphological traits were used as well as flux cytometry analysis to confirm the success of interspecific crosses. High phenotypic diversity was estimated both within and between hybrid groups. Plants of all WH hybrids and 50\% of $\mathrm{CH}$ hybrids were rather similar to respective parents from the behavior and morphological points of views. The remaining $\mathrm{CH}$ hybrids were closer to their cultivated parent for phenotypical characteristics, vernalization requirement, and biannual vegetative cycle. Heritability rate in progeny generation was variable for cultivated and wild types, $\mathrm{H} 2 \mathrm{WP}=3-95 \% / \mathrm{H} 2 \mathrm{CP}=3$ $91 \%$ and of $\mathrm{H} 2 \mathrm{WP}=4-89 \% / \mathrm{H} 2 \mathrm{CP}=3-89 \%$. Diploid and tetraploid cytotypes were observed in hybrids and their parents. Tetraploid plants of Beta macrocarpa detected for the first time in Morocco provide novel insights on the cytogenetic diversity of Beta genus. The results obtained in this study show that Moroccan beet germplasm might provide a valuable reservoir of gene to improve genetic and cytogenetic diversity, adaptation and resistance to biotic and abiotic.
\end{abstract}

Key words: sugar beet, interspecific hybridization, phenotypical characterization, ploidy level.

\section{Introduction}

Beta L. (Betoideae Ulbr., Chenopodiaceae Vent.) compreises 9 species, whereas the number of infraspecific taxa (subspecies and varieties) is undefined at present including both wild and cultivated morphotypes which are mainly included in the high variable Beta vulgaris L. (see e.g., Kadereit \& al. 2006; Uotila 2011; Iamonico 2019).

The classification of the genus (and the whole subfamily Betoideae) was recently revised by Iamonico (2019) who recognized two tribes, i.e. Beteae (Moq.) G. Kadereit \& al. and Halbitziae Ulbr.; for the tribe Betae three sections and four subsections were accepted. 
The Flora of Morocco includes native Beta species, i.e. Beta macrocarpa Guss. and (sugar beet) (see El Bahloul 2007; Uotila 2011; Hellier \& al. 2013). Sugar beet (Beta vulgaris s. 1.) is a relatively young crop in Morocco, which supposedly has a narrow genetic base. Natural genetic diversity in wild Beta species, including B. macrocarpa, is used for genetic improvement of cultivated beet.

Beta macrocarpa [Beta sect. Macrocarpae Iamonico (Iamonico 2019: 154)] is a widespread species in the central-west Mediterranean basin (Pottier-Alapetite 1979; Uotila 2011). In Morocco, it is widely found on the inland $30 \mathrm{~km}$ away from the sea and up to $1000 \mathrm{~m}$ above sea level, on balanced and non-saline soils (El Bahloul \& al. 2006; El Bahloul 2007). While this herbaceous annual plant has also been considered as a halophytic or semi-halophytic species, mostly grown in coastal lands (within $1 \mathrm{~km}$ of the sea). It is mainly found in disturbed habitats (Flowers \& al. 1977; Hessini \& al. 2005; Slama \& al. 2016). Many authors reported that this species contains diploid, tetraploid and hexaploid cytotypes (Letschert 1993; Castro \& al. 2013; Leys \& al. 2014). Tetraploid and hexaploid cytotypes were first reported in the Canary Islands and in Portuguese territory. This variability of polyploidization level is probably resulting from allopolyploidy hybridizations between $B$. macrocarpa and $B$. vulgaris subsp. maritima (L.) Arcang. (Villain 2007). From the genetical point of view, high genetic diversity is attributed to $B$. macrocarpa with occurrence of some unique isozyme alleles (Nagamine \& al. 1989; Abe \& Shimamoto 1989).

For these reasons, B. macrocarpa wild germplasms might provide a valuable reservoir of resistant genes to biotic and abiotic stress (Peltier \& al. 2012; Fan \& al. 2015; Slama \& al. 2016). That could potentially be used for sugar beet breeding and improvement. The introduction of important agronomic characteristics of wild B. macrocarpa into cultivated beets is generally operated through interspecific crosses. Hybridization using a genetic locally material will generate new combinations of traits and will increase the adaptability to local environments (Abbott \& al. 2013; Soltis \& al. 2015).

The present work aims: 1) to succeed in obtaining viable interspecific hybrids resulting from crosses between annual wild $B$. macrocarpa (plant) and biannual cultivated sugar beet (B. vulgaris subsp. vulgaris) grown locally under the Moroccan environmental conditions; 2 ) to evaluate agro-morphological diversity within hybrids and between hybrids and their parents; 3 ) investigate the behavior of both hybrid plants collected on cultivated and wild parents separately; 4) evaluate heritability of studied traits; 5) characterize the ploidy levels of the beet hybrids and their parents. This study represents the first evaluation of Moroccan B. macrocarpa and its prospective implication in breeding program at national scale.

\section{Material and methods}

Plant material - Interspecific hybridizations have been carried out between wild ( $B$. macrocarpa) and cultivated beet (B. vulgaris subsp. vulgaris).

Parental plant material involved in interspecific hybridizations, consisted of two populations of B. macrocarpa collected two different sites in Morocco (Fès, center of north of Morocco at $820 \mathrm{~m}$, and Ouajda in the extreme north-east at $463 \mathrm{~m}$ ) during the reproductive period in 2010. 15 individuals were collected from each wild population and grown in the greenhouse under controlled conditions and spatial isolation. 
Two different half-sib families of sugar beet originating from the national breeding program were used as cultivated parents. 25 seeds from each family were planted at Merchouch, experimental station of the National Institute of Agronomic Research-Morocco $\left(33^{\circ} 36^{\prime} 48.8^{\prime \prime} \mathrm{N} ; 6^{\circ} 43^{\prime} 03.3^{\prime \prime} \mathrm{W} ; 340 \mathrm{~m}\right.$ a.s.1.). Plants required a period of vernalization.

Experimental field was characterized by an annual cumulative rainfall ranging from 246.4 to $542.8 \mathrm{~mm}$ and a mean temperature reaching $4{ }^{\circ} \mathrm{C}$ in January and $45^{\circ} \mathrm{C}$ in August during 2017 and 2018.

Hybrids evaluation trial was conducted in the greenhouse under semi-controlled conditions at $25 \pm 2{ }^{\circ} \mathrm{C}$, a $16 / 8 \mathrm{~h}$ light/dark regimen and relative humidity rate above $60 \%$. A month after seeds sowing, seedlings of uniform size were transplanted in black hard plastic pots (one plant per pot), under spatial isolation. A total of 75 viable hybrids, 35 collected from wild parent and 40 from cultivated parent, were evaluated.

Hybridization technique - Two genotypes were randomly selected from wild populations and cultivated plants of sugar beet for the interspecific crosses, that have flourished in very close periods.

In October 2017, the samples of cultivated beet $B$. vulgaris subsp. vulgaris were transplanted to the field one month after sowing. To synchronize flowering season between parental forms, annual genotypes of Beta macrocarpa were sown in an average period of 70 days after sowing date of biannual cultivated genotypes.

Before flowering time, wild plants were transported to the field. Two branches, one from each plant, were bagged with white parchment bags $(12 \times 18 \mathrm{~cm})$ to control interspecific hybridization until the end of the reproductive phase and seed formation. The maternity of each seed is known. At maturity, seed-balls were harvested from both wild (WH01 and $\mathrm{WH}-02)$ and cultivated $(\mathrm{CH}-01$ and $\mathrm{CH}-02)$ branches separately. Parent genotypes were sown and characterized based on agro-morphological characteristics in 2016-2017, one year before the evaluation of interspecific crosses.

Agro-morphological approach - A total of 21 morphological traits (Table 1), including 16 quantitative and 5 qualitative were analyzed following the Beta descriptors published by Bioversity International (formerly IPGRI, 1991) for characters related to vegetative and reproductive, developmental stages and yield. Concerning leaf characters, 10 leaves were randomly measured from each studied genotype. The measurements were carried out on the plants before bolting at a consistent stage to standardize the morphological evaluation.

Cytogenetic approach - Ploidy level was evaluated using flow cytometry procedure for nuclear isolation (Galbraith \& al. 1983). Analyses were performed on young leaves obtained from 4 different hybrid groups (WH-01, WH-02, CH-01 and CH-02), 2 wild and 2 cultivated parent genotypes.

Analysis were performed by Partec CyFlow Space flow cytometer (Partec GmbH., Görlitz, Germany) Nuclei isolated from $5 \mathrm{~mm} 2$ discs of leaf tissue of fresh tissue were finely chopped with a sharp razor blade in a Petri dish (diameter, $5 \mathrm{~cm}$ ) placed in the presence of $400 \mu \mathrm{l}$ of extraction buffer $(0.2 \mathrm{M}$ Tris- $\mathrm{HCl}, 4 \mathrm{mM} \mathrm{MgCl} 2 \cdot 6 \mathrm{H} 2 \mathrm{O}, 1 \%$ Triton X100, 2 mM Disodium Ethylene Dinitrilo Tetraacetic acid EDTA Na2.2H2O, 86 mM NaCl, $10 \mathrm{mM}$ metabisulfite, $1 \%$ PVP-10, $\mathrm{pH}$ adjusted to 7.5) at room temperature. Nuclear suspension was then filtered using a $50 \mu$ m nylon filter and $1.6 \mathrm{ml}$ of CyStain ${ }^{\circledR}$ solutions from Sysmex Partec (containing 4', 6-diamidino-2-phenylindole: DAPI) was added to the sam- 
210 Oumouss \& al.: Phenotypic and cytogenetic diversity of local beet hybrids from ...

Table 1. Agro-morphological descriptors used to characterize interspecific hybrids and their parents. 0

\begin{tabular}{|c|c|c|}
\hline \multirow{6}{*}{ 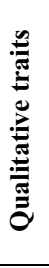 } & Descriptor & Measurement and rating scales \\
\hline & Leaf color & $1=$ Yellow $; 2=$ Light green , $3=$ Green \\
\hline & Petiole color & $1=$ White $; 2=$ Yellow , $3=$ Green $; 4=$ Pink ; $5=$ Red \\
\hline & Stem color & $1=$ Green $; 2=$ Green and red ; $3=$ Red \\
\hline & Leaf pigmentation & $0=$ Absent $; 1=$ Spotted $; 2=$ Red vein $; 3=$ Entire red \\
\hline & Growth habit & $\begin{array}{l}1=\text { Erect } ; 2=\text { Erect and procumbent; } 3=\text { Procumbent; } 4 \\
=\text { Erect and prostrate; } 5=\text { Prostrate }\end{array}$ \\
\hline \multirow{16}{*}{ 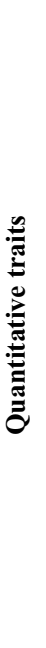 } & Leaf blade width & Centimeter $(\mathrm{cm})$ \\
\hline & Petiole length & Centimeter $(\mathrm{cm})$ \\
\hline & Petiole width & Centimeter $(\mathrm{cm})$ \\
\hline & Plant height & Centimeter $(\mathrm{cm})$ \\
\hline & Rosette diameter & Centimeter $(\mathrm{cm})$ \\
\hline & Number of stem & Main stem + side stems \\
\hline & Number of days to germination (days) & From sowing to seedling emergence \\
\hline & Germination rate & Percentage $(\%)$ \\
\hline & Number of days at bolting (days) & From sowing to main stem elongation \\
\hline & Number of days to flowering (days) & From sowing to the start of flowering \\
\hline & Flowering time (days) & From the beginning to the ending of flowering \\
\hline & Number of days at seed formation (days) & From sowing to seeds formation \\
\hline & Life span (days) & From sowing to last harvest \\
\hline & Number of seeds plant ${ }^{-1}$ & At the end of the vegetative cycle \\
\hline & Weight of seeds plant ${ }^{-1}$ & Gramme (g) \\
\hline & Weight of 1000 seeds & Gramme $(\mathrm{g})$ \\
\hline
\end{tabular}

ple tubes to stain the DNA. To calibrate the output, the first sample introduced in the flow cytometer was the external standard, in this study, it was a diploid Beta vulgaris subsp. maritima plant (reference standards with $2 n=2 \mathrm{x}=18$ ). The voltage of the photomultiplier was adjusted in order to fix the signal of the diploid standard at channel position 200 . During the course of the flow cytometric measurements of samples of unknown ploidy, diploid and tetraploid signals, respectively, were fixed at positions 200 and 400.

Data analysis - Morphological data were statistically analyzed using SPSS software (version 23). Variations among the hybrid plants for each morphological trait were computed using the analysis of variance (ANOVA). Coefficients of variation (CV\%) were calculated for each quantitative parameter. Principal component analysis (PCA) was carried out on hybrids using the 14 quantitative characters we considered (see e.g., Kiers 1989; Agudelo-Jaramillo \& al. 2016). Similarly, the linear regression coefficient was computed to obtain an estimate of broad sense heritability in quantitative traits (Hansche \& al. 1972). Heritability analysis concerned wild parent $\left(\mathrm{H}^{2}{ }_{\mathrm{WP}}\right)$ and cultivated parent $\left(\mathrm{H}^{2}{ }_{\mathrm{CP}}\right)$. Two traits related to the number and weight of seeds per plant were excluded from PCA and linear regression analyses, due to the clear difference between grain yield of cultivated and wild plants. For the morphological qualitative characteristics, the frequency distribution of each morphotype was evaluated. 


\section{Results}

\section{Phenotypical characterization}

Characterization data of four parent populations and progeny groups, harvested both on wild (WH-01 and WH-02) and cultivated genotypes (CH-01 and $\mathrm{CH}-02)$ were analyzed as follow.

\section{Qualitative agro-morphological traits}

The high variation was found in the hybrid groups, WH and $\mathrm{CH}$ for qualitative morphological descriptors (Fig. 1). The most differentiating traits are colour of petiole and stem, pigmentation of leaves, and habit. On the contrary, homogeneous character is green colour of the blades which was observed in both parental (WP and CP) and progeny groups (WH and $\mathrm{CH}$ ). Hybrid beet plants showed petioles with three different colour characteristics (green, red, and red-streaked) and two morphotypes related to stem colour (green and green/red in variable proportions; Fig. 1, A and B). These hybrids were generally characterized by green leaves without any pigmentation. However, the accumulation of red pigments in leaf veins was recorded at a percentage of $22.2 \%$ and $10 \%$ in $\mathrm{WH}$ and $\mathrm{CH}$ hybrids, respectively (Fig. 1, C). Regarding phenotypic profiles related to habit (Fig. 1, D), erect plants are predominant and commonly observed in the hybrids. Another morphotype (erect and procumbent) was identified at a frequency of $33.33 \%$ and $10 \%$ noticed in WP and $\mathrm{HC}$ genotypes, respectively.

For parent generation's qualitative phenotypic traits, wild and cultivated genotypes showed a lack of red pigmentation on leaf blade, petiole, and stem, except for the stems in wild parents (WH). The studied wild genotypes display erect habit, as well. Erect habit was observed in CP cultivated parents with erect and procumbent habit, at an equal frequency of 50\%.

Red pigmentation was not overly present in all wild and cultivated beet genotypes. Therefore, it is probably an inherited trait from wild parent and transmitted to WH hybrids in particular, with a relatively higher percentage for red petioles $(44.44 \%)$, red /green petioles $(22.22 \%)$ and red veins $(23 \%)$, compared to $10 \%$ recorded for this three morphotypes in $\mathrm{CH}$ hybrids. This could be explained by the expression of hidden or recessive alleles in WP parent, and expressed through the progeny. The results revealed that $\mathrm{CH}$ hybrids are more similar to cultivated parents ' $\mathrm{CP}$ '. Green stems observed in a much higher percentage in WH hybrids (89\%) from wild parents, compared to $\mathrm{CH}$ hybrids $(80 \%)$, suggests the predominant heritability of this morphotype by cultivated maternal parent. The red/green stems were observed at low frequency [but higher in $\mathrm{CH}(20 \%)$ if compared to $\mathrm{WH}$ (11.11\%)] and was probably an intermediate phenotype inherited by both parents. Basically, $\mathrm{CH}$ hybrids tend to be similar to cultivated parents for the green coloured stems (78.6\%), in comparison with wild parents. Wild parent "Beta macrocarpa" was involved in the transmission of erect habit to progeny, at a frequency of $90 \%$ and $67 \%$ in $\mathrm{CH}$ and WH hybrids, respectively. While the erect/procumbent habit observed in WH hybrids $(22.22 \%)$ with a higher percentage than $\mathrm{CH}(10 \%)$ could be an inherited morphotype from their cultivated parents.

All things considered, both WH and $\mathrm{CH}$ hybrid plants show an intermediate level of petiole and stem colour, growth habit, and leaves pigmentation between their parents (Fig. 1). 


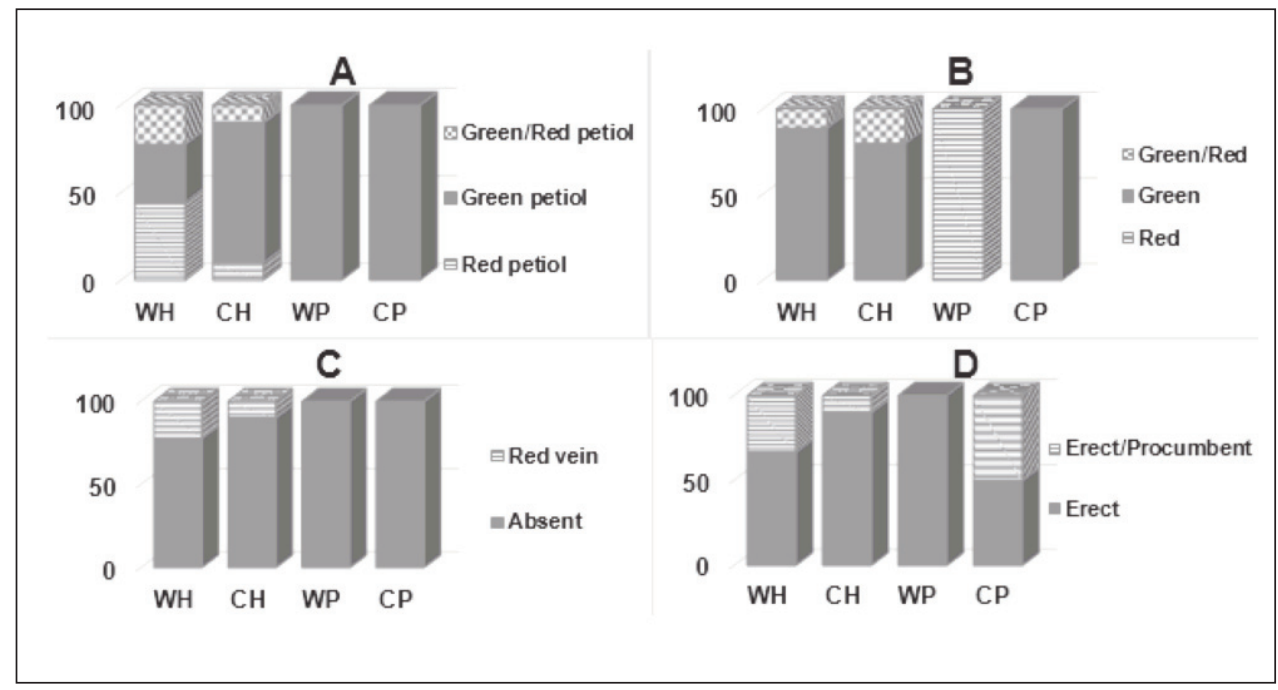

Fig. 1. Qualitative traits related to petiole color (A), stem color (B), leaf pigmentation (C) and growth habit (D), used for the phenotypic characterization of "WH/CH" hybrids obtained from crosses between Beta vulgaris subsp. vulgaris $\times$ B. macrocara, as well as their wild parents "WP" and cultivated parents "CP".

\section{Quantitative agro-morphological traits}

\subsection{Characterization and variation study}

ANOVA analysis of all quantitative phenotypic data showed statistically significant difference among the two hybrid groups $\mathrm{WH}$ and $\mathrm{CH}$, excepting for the width of petiole (Table 2). A genetic variation among the evaluated beet hybrid genotypes is generated by the crosses.

According to seed maternity, highly significant differences were recorded for descriptors related to the size (length and width) of leaf blade and plant height, as well as to number of days to germination, bolting, flowering, seed formation, number and weight of seeds per plant, and 1000-seeds weight, observed in WH hybrids from wild maternal branch, compared to their cultivated parent CP. Analysis of variance also showed a significant difference between $\mathrm{CH}$ hybrids and their cultivated parents for width of leaf blade, plant height, rosette diameter, flowering, reproduction, number and weight of seeds per plants and 1000-seeds weight. A moderate difference was observed between $\mathrm{CH}$ hybrids and their wild relatives for the germination trait (Table 2).

Coefficient of variation (CV) was calculated for each agro-morphological trait (Table 2). $\mathrm{CV} \%$ values were generally variable in beet hybrid groups. They ranged from $6.68 \%$ to $70.47 \%$ in $\mathrm{WH}$ and from $6.95 \%$ to $76.17 \%$ in $\mathrm{CH}$. In the parental forms, $\mathrm{CV} \%$ values were variable, ranging from $0 \%$ to $111.06 \%$ for wild parents and of $5.28 \%$ to $91.04 \%$ for cultivated parents.

Mean values of quantitative traits comparative study, provided a clear phenotypic characterization between the two types of hybrids (Table 2). Hybrids harvested from cultivated maternal parent $(\mathrm{CH})$ were characterized by developed plant biomass and extensive 
Table 2. Means of quantitative traits used for morphological classification of local hybrids, wild and cultivated parents of Beta vulgaris subsp. vulgaris.

\begin{tabular}{|c|c|c|c|c|}
\hline Variables & WP & WH & $\mathbf{C H}$ & $\mathbf{C P}$ \\
\hline Leaf blade length $(\mathrm{cm})$ & 10.42 & $8.03^{* * * \mathrm{CP}}$ & $10.45^{* * *}$ & 16 \\
\hline Leaf blade width $(\mathrm{cm})$ & 6.22 & $6.48^{* * * \mathrm{CP}}$ & $8.23^{* * * \mathrm{CP}}$ & 14 \\
\hline Petiole length $(\mathrm{cm})$ & 12.71 & $13.13^{* * *}$ & $11.27^{* * *}$ & 14 \\
\hline Petiole width $(\mathrm{cm})$ & 0.35 & 0.33 & 0.5 & 1 \\
\hline Number of stem $(\mathrm{cm})$ & 4.5 & $4.67^{* * *}$ & $5^{* * *}$ & 10 \\
\hline Plant height $(\mathrm{cm})$ & 53 & $48.89^{* * * \mathrm{CP}}$ & $63.6^{* * * \mathrm{CP}}$ & 119 \\
\hline Rosette diameter $(\mathrm{cm})$ & 46.25 & $48.69^{* * *}$ & $37.7^{* * \mathrm{CP}}$ & 60 \\
\hline Number of days to germination (days) & 22 & $14^{* * * \mathrm{CP}}$ & $15.6^{* * \mathrm{WP}}$ & 7 \\
\hline Number of days at bolting (days) & 83 & $80.67^{* * *} \mathrm{CP}$ & $78.33^{* * * \mathrm{CP}}$ & 237 \\
\hline Number of days to flowering (days) & 88.5 & $111.7^{* * *} \mathrm{CP}$ & $123.3^{* * *} \mathrm{CP}$ & 240 \\
\hline Flowering time (days) & 15.5 & $12.11^{* * *}$ & $11.75^{* * *}$ & 48 \\
\hline Number of days at seed formation (days) & 181.5 & $143.7^{* * * \mathrm{CP}}$ & $151^{* * * \mathrm{CP}}$ & 261 \\
\hline Life span (days) & 257.5 & $170.2^{* *}$ & $194.3^{* *}$ & 309 \\
\hline Number of seeds/plants & 57.5 & $144.4^{* * * *} \mathrm{CP}$ & $175^{* * * \mathrm{CP}}$ & 2598 \\
\hline Weight of seeds/plant $(\mathrm{g})$ & 0.65 & $3.67^{* * *} \mathrm{CP}$ & $2^{* * *} \mathrm{CP}$ & 133 \\
\hline Weight of 1000 seeds $(\mathrm{g})$ & 11.33 & $22.85^{* * *}$ & $14.8^{* * *}$ & 22 \\
\hline CV (\%) interval & $0-111.06$ & $6.68-70.47$ & $6.95-76.17$ & $5.28-91.04$ \\
\hline
\end{tabular}

(*) significant difference $\left({ }^{*} P<0.05,{ }^{* *} P<0.01,{ }^{* * *} P<0.001\right)$. CV: coefficient of variation. WP: Wild Parent "Beta macrocarpa"; CP: Cultivated Parent "Beta vulgaris subsp. vulgaris"; WH: hybrids from wild maternal branch; $\mathrm{CH}$ : hybrids from cultivated maternal branch.

branching, late vegetative and reproductive stages, and higher number of seeds per plant. On the other hand, hybrids from wild maternal parents (WH) had relatively low aboveground biomass and a higher grain yield. These hybrids were characterized by early stages of plant development, a relatively late bolting stage with an average of 2 days compared to $\mathrm{CH}$ hybrids.

\subsection{Heritability and phenotypic similarity}

Phenotypic relatedness between progeny and their parents was estimated by parent-offspring regression $\left(\mathrm{H}^{2}\right)$ from quantitative morphological data (Fig. 2).

High heritability (more than $50 \%$ in percentage) was obtained according to wild parental genotypes for width of leaf blade $\left(\mathrm{H}^{2}{ }_{\mathrm{WP}}=54-78 \%\right)$ and number of stems $\left(\mathrm{H}^{2}{ }_{\mathrm{WP}}=63-69 \%\right)$ in WH hybrids. High heritability was also estimated in the progeny of WH-01 for petiole width $\left(\mathrm{H}^{2}{ }_{\mathrm{WP}}=54 \%\right)$, leaf diameter $(50 \%)$, bolting $\left(\mathrm{H}^{2}{ }_{\mathrm{WP}}=51 \%\right)$ and cycle length $\left(\mathrm{H}^{2}{ }_{\mathrm{WP}}=67 \%\right)$, compared to their wild relative. However, a dominant phenotypic inheritance from cultivated parents was potentially noted in WH-01 hybrids for germination performance $\left(\mathrm{H}^{2}{ }_{\mathrm{WP}}=95 \%\right)$.

In $\mathrm{CH}$ hybrids, traits related to leaf blade width $\left(\mathrm{H}^{2}{ }_{\mathrm{CP}}=64-82 \%\right)$ and plant height $\left(\mathrm{H}^{2}{ }_{\mathrm{CP}}\right.$ $=68-88 \%$ ) showed a high level of heritability from cultivated parent. Cultivated parent was also involved in the transmission of phenotypic traits at relatively high percentages (50\%) for germination, $61 \%$ for span life and $53 \%$ for 1000 -seed weight, to $\mathrm{CH}-01$ hybrids. While a high heritability was estimated between $\mathrm{CH}-01$ hybrids and their wild relatives for quantitative traits related to petiole length $\left(\mathrm{H}^{2}{ }_{\mathrm{WP}}=89 \%\right)$, leaf diameter $\left(\mathrm{H}^{2}{ }_{\mathrm{WP}}=\right.$ $76 \%)$, and branching $\left(\mathrm{H}^{2}{ }_{\mathrm{WP}}=71 \%\right)$. 




Fig. 2. Histograms of $\mathrm{H}^{2}$ based on R-square values of parent-offspring regression for fourteen quantitative traits of beet interspecific hybrids: (A) Leaf blade length, (B) Leaf blade width, (C) Petiole length, (D) Petiole width, (E) Number of stems, (F) Plant height, (G) Rosette diameter, (H) Number of days to germination, (I) Number of days at bolting, (J) Number of days to flowering, (K) Flowering time, (L) Number of days at seed formation, (M) Life span and (N) 1000-seeds weight. WP = wild maternal parent and $\mathrm{CP}=$ cultivated maternal parent.

Eigenvalues obtained by the PCA for the 14 quantitative morphological traits indicated that two first components explained $78.30 \%$ of the total variability (Table 3). Eight variables showed high correlation with the first eigenvectors (component 1), namely blade length, blade width, petiole width, number of stems, plant height, number of days at bolt- 
Table 3. Eigenvalues of the Principal Component as well as the percentage of the total variance accounted for each component.

\begin{tabular}{|l|r|r|}
\hline \multirow{2}{*}{ Variable } & $\mathbf{2}$ \\
\cline { 2 - 3 } & & Composant \\
\hline Leaf blade length (cm) & $\mathbf{0 . 7 8}$ & 0.50 \\
\hline Leaf blade width (cm) & $\mathbf{0 . 7 3}$ & 0.48 \\
\hline Petiole length (cm) & 0.04 & -0.29 \\
\hline Petiole width (cm) & $\mathbf{0 . 8 3}$ & 0.49 \\
\hline Number of stem (cm) & $\mathbf{0 . 8 8}$ & 0.46 \\
\hline Plant height (cm) & $\mathbf{0 . 8 7}$ & 0.26 \\
\hline Rosette diameter (cm) & 0.30 & 0.34 \\
\hline Number of days to germination (days) & -0.35 & $\mathbf{- 0 . 9 1}$ \\
\hline Flowering time (days) & 0.29 & $\mathbf{0 . 9 0}$ \\
\hline Number of days at bolting (days) & $\mathbf{0 . 8 1}$ & 0.53 \\
\hline Number of days to flowering (days) & 0.62 & $\mathbf{0 . 7 7}$ \\
\hline Number of days at seed formation (days) & $\mathbf{0 . 9 0}$ & 0.34 \\
\hline Life span (days) & $\mathbf{0 . 9 5}$ & 0.17 \\
\hline Weight of 1000 seeds (g) & 0.54 & $\mathbf{0 . 8 3}$ \\
\hline \% of variance & $\mathbf{7 3 . 3 3}$ & $\mathbf{1 3 . 9 7}$ \\
\hline
\end{tabular}

ing, number of days to formation and life span. Number of days to germination, flowering time, number of days to flowering, and 1000-seed weight traits showed high correlation with the second eigenvectors (component 2).

Three distinct groups occur in PCA analysis (Fig. 3):

1) group 1: it comprises all WH interspecific hybrids (WH-01 and WH-02) as well as $\mathrm{CH}-01$ hybrid, which represent $69 \%$ of total studied genotypes. This group was characterized by short, broad leaf blades, reduced height and low branching. The hybrid plants of this group are characterized by early bolting (73.03 days), productivity (138.06 days) and maturity (169.89 days) than the two parents (WP and CP). The wild parent has an annual cycle of 257.50 days and small vegetative size, against the well-developed vegetative mass of the cultivated parent with biennial cycle of 311.40 days;

2) group 2: hybrid plants of $\mathrm{CH}-02$ and their cultivated parent (CP) were grouped together. This group was distinguished by a much more developed plant biomass and significant branching. Hybrid plants remained in the vegetative state without being able to flower the first year under the homogeneous conditions of the greenhouse. A high phenotypic similarity was revealed between all plants of this hybrid with their cultivated parent;

3) group 3: it includes WP parental genotypes, showed low aboveground biomass and grain yield. Plants of this group were characterized by early development stages with an annual cycle.

\section{Cytogenetical characterization}

Both diploid and tetraploid cytotypes were found in tested interspecific hybrids as well as their wild and cultivated parents. Diploid and tetraploid hybrids were obtained from interspecific hybridizations of diploid B. macrocarpa $\times$ diploid B. vulgaris s. s. and 
216 Oumouss \& al.: Phenotypic and cytogenetic diversity of local beet hybrids from ...

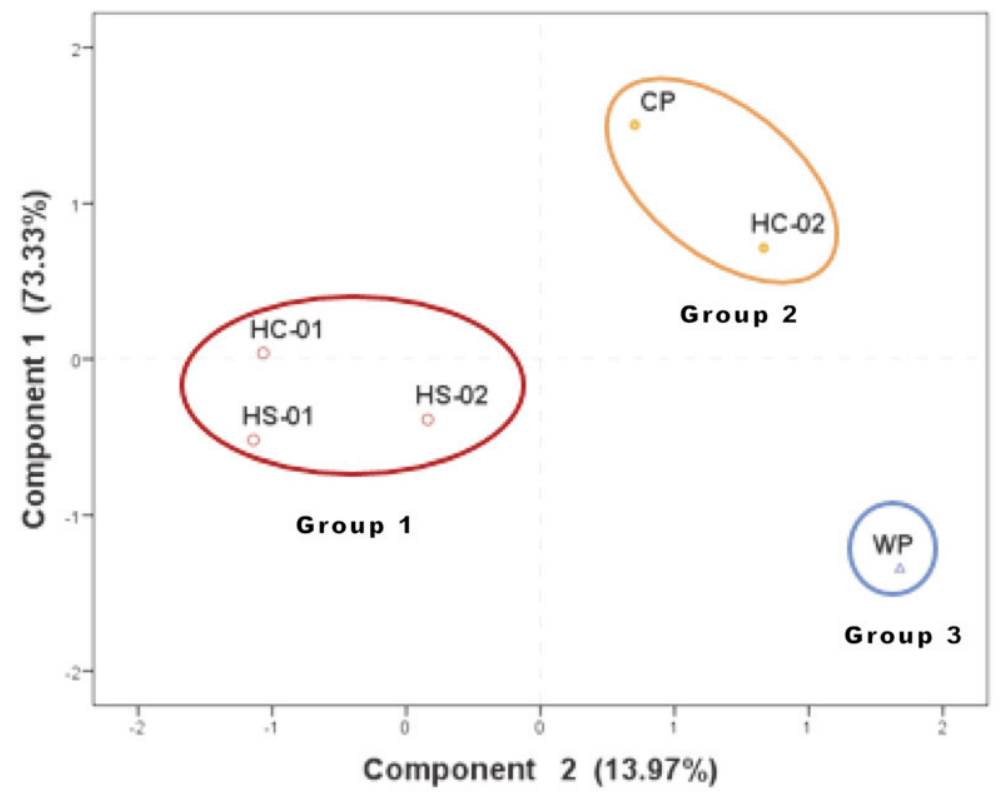

Fig. 3. PCA of interspecific hybrid and parent groups based on fourteen phenotypic traits upon the first two axes, explaining $87.30 \%$ of the total variation. $\mathrm{WP}=$ wild parent of Beta macrocarpa, $\mathrm{CP}=$ cultivated parent of Beta vulgaris subsp. vulgaris, $\mathrm{WH}=$ hybrid from wild maternal branch, $\mathrm{CH}=$ hybrid from cultivated branch.



Fig. 4. Relative fluorescence histograms of DAPI (4', 6-diamidino-2-phenylindole) stained nuclei isolated from fresh leaf tissues of diploid (A) and tetraploid (B) interspecific hybrids of beet. Simultaneous analysis of nuclei isolated from Beta vulgaris subsp. maritima $(2 n=2 \mathrm{x}=18)$ used in this study as a reference standard. 
tetraploid B. macrocarpa $\times$ tetraploid B. vulgaris s. S., respectively. Presence of tetraploid B. macrocarpa genotypes $(2 n=36)$ is very rare in nature (see Letscher 1993; Iamonico, 2019) and was detected for the first time in Moroccan germplasm in this study.

\section{Discussion}

Natural hybridization between $B$. vulgaris subsp. vulgaris and B. macrocarpa is apparently absent in Morocco. Sugar beet production areas are not vernalizing zones and no seed production is operated in the country. Bolting-resistant sugar beets grown in the Moroccan cultivated field, are mainly intended for sugar production and not for seed production. General climate prevailing in Morocco is not favorable for the induction of flowering in sugar beet, except for some very limited vernalizing areas, as "Merchouch". Only few specific zones are used for experiments and trials.

Obtaining a viable and fertile hybrid between $B$. macrocarpa $\times$ B. vulgaris subsp. vulgaris, for the first time under Morocco climatic conditions, is a great success giving originality to our work. All obstacles of interspecific hybridizations of B. vulgaris s. s. were overcome by establishing favorable conditions for crosses between wild annual species and biennial sugar beet, in terms of synchronization of the flowering period as well as by choice of experimental site favorable to flowering induction seed production in cultivated beet.

Under the vernalizing climatic conditions during the study, cultivated sugar beet genotypes required a cold period of 4 to $7{ }^{\circ} \mathrm{C}$ to induce bolting and flowering, 65 to 77 days after sowing. In most commercial cultivars of sugar beet, requires a cold period from 10 to 16 weeks of exposure to optimal temperatures between $4^{\circ} \mathrm{C}$ and $6^{\circ} \mathrm{C}$ (McGrath 2018). Cold period was reported to influence the probability of flowering in beet (Van Dijk \& Desplanque 1999; Boudry \& al. 2002; Reeves 2007).

The high variability observed among the hybrid plants, indicates that genetic segregating process between parents was established. Several qualitative morphotypes have been observed in the progeny, showing a high phenotypic diversity. New morphotypes reveled in the hybrids, and not presented in parental genotypes, could be explained by the expression of hidden or recessive alleles in parents, which were expressed through the progeny. An example is the red pigmentation by WP wild parents or the erect and procumbent habit by $\mathrm{CP}$ cultivated parents. In general, studied hybrids presented an intermediate behavior between the two parents regarding the studied descriptive parameters, in particular $\mathrm{WH}-$ 01, WH-02 and CH-01, with a spontaneous flowering and annual vegetative cycle. $\mathrm{CH}-02$ hybrid from the cultivated maternal branch is more similar to their cultivated parent for vernalization requirement, indicating probably the recessive inheritance B-gene by cultivated parent. However, it has been shown that beet genotypes carrying the dominant B allele flower under long days without vernalization requirement (Van Dijk \& al. 1997; Boudry \& al. 1994; Hôft \& al. 2018). Vernalization requirement appears to be strongly related to temperature, photoperiod, geographical latitudinal gradients cold treatment (Boudry \& al. 2002; Limin \& Fowler 2006; Rhoné \& al. 2008; Michael \& al. 2020).

Phenotypic variation detected, between and within hybrids, would be explained by the allogamy and cross-fertilization of Beta species and infraspecific taxa, and to genetic richness of $B$. macrocarpa probably associated with its wide adaptative capacity. Studied wild 
genotypes were originated from arid and semiarid inland regions, where climate is generally characterized by extreme seasonal variations in temperatures in addition to low rainfall. The studied genotypes could serve as a source of genes for genetic improvement to biotic and abiotic resistance stress, through the accumulation of genetic variation (Cholastova \& Knotova 2012; Böhm \& al. 2017; Biancardi \& al. 2012; 2020).

For the first time in 1975, McFarlane reported natural hybrids, with the characteristics of segregates between B. vulgaris subsp. vulgaris and B. macrocarpa in the Imperial Valley, California. He speculated that the presence of male sterility in the identified hybrid plants ( $7 \%$ of the total studied plants) arose from crosses between a male-sterile mother and B. macrocarpa. McFarlane (1975) also theorized that seeds of B. macrocarpa species are thought to have been introduced from the Mediterranean area prior to 1928 .

We detected for the first time of tetraploid cytotypes in Beta macrocarpa and in beet hybrids. Tetraploid Beta macrocarpa genotypes are rarely found in nature, they were exclusively sampled in Canary Island and in Portugal mainland (see e.g., Bartsch \& al. 2003; Villain 2007; Castro 2013). Authors of earlier studies, were of the opinion that all plants of B. macrocarpa, growing on the Canary Islands are tetraploid (Buttler 1977; Lange \& al. 1989). It has been suggested that the origin of tetraploid cytotype discovered in Beta macrocarpa populations of Canary Islands result probably from at allopolyploidy hybridization events between diploid $B$. macrocarpa and $B$. vulgaris subsp. maritima (Buttler 1977; Villain 2007).

Tetraploid B. macrocarpa genotypes found in the Moroccan collection, supports the hypothesis of existing of seed and pollen flow contributing to the transfer of genes, species colonization into new environment and dissemination in time and space of tetraploid $B$. macrocarpa populations from the Portugal or Canary Islands, as land areas are geographically close to Morocco.

Infrequency of tetraploid cytotype could be explained by the competitive ability of pollen released by diploid beet is much higher compared to pollen produced by tetraploid plants, as suggested by Scott \& Longden (1970). Indeed, only few triploids (3n) see beet individuals were detected during collections in 17 Danish seas, showing that the levels of gene flow from tetraploid pollinators are very low (Andersen \& al. 2005). In a first study on natural polyploidy in wild populations of annual beet, Buttler (1977) reported that plant morphology and pollen diameter were useless for distinguishing diploid and tetraploid types of B. macrocarpa. This was in consistent with our results which show that diploid and tetraploid hybrid plants did not show a difference in their morphology. Kishima \& al. (1987) reported a difference in restriction fragment pattern of chloroplast DNA of diploid and tetraploid B. macrocarpa.

Studied hybrids represent a percentage of $83 \%$ of viable plants with normal growth. However, the remaining $17 \%$ on-germinating seeds could be non-viable seed triploid plants. In this context Trueblood and his team (2010) showed that seedlings produced by the triploid clone in Hypericum androsaemum L. died shortly after germination. According to Nghiem $\&$ al. (2018), less than $25 \%$ of germinated progeny from triploid clone of Acacia Mill. (between tetraploid A. mangium and diploid A. auriculiformis). survived at 3 months after sowing with sever stunting and arrested growth. Our results could prove the success of the hybridization seed method with a complete control to avoid external pollen crosses (controlled pollination) and that hybridization was carried out under full isolated conditions. 


\section{Conclusion}

In order to use Moroccan B. macrocarpa genotypes as a natural reservoir of gene and genetic diversity for adaptation to abiotic and biotic constraints and for broadening the genetic base of sugar beet, interspecific hybridizations were carried out. Efforts were focused on developing the appropriate environment for developing hybrids adapted to Moroccan climatic conditions.

Obtaining a viable and fertile beet hybrid resulting from B. macrocarpa (rare in nature) is an important and encouraging step towards the genetic improvement of sugar beet.

Hybrid showed a wide variability of morphological and developmental characteristics. The majority of the hybrids (WH hybrids harvested in wild maternal plants and $50 \%$ of $\mathrm{CH}$ hybrids cultivated maternal plants) are annual plants. They showed normal seed set within the first year without any vernalization requirements, probably explaining the considerable impact of the wild parent performance for the transmission of phenotypic traits to the progeny. Remaining $\mathrm{CH}$ hybrids were closer to their cultivated parent for biomass, branching, and vernalization requirement.

Tetraploid cytotypes in Beta macrocarpa were here first detected in Morocco with natural polyploidy in sect. Beta. Results provide novel insights on the genetic and cytogenetic diversity of Beta genus for breeding programs and biodiversity for climate change adaptation.

\section{Acknowledgments}

The flow cytometric analysis of ploidy in this research was performed in National Institute of Agronomy Research Kenitra - Morocco with support of Dr. Hassan Benaouda and under the supervision of Dr. Hamid Benyahia. We are grateful to the whole team as well as to Dr. Ouiam Chettou and Dr. Majda Stitou for their precious assistance and their contribution to perform the cytometric part of this study.

\section{References}

Abbott, R. J., Albach, D., Ansell, S., Arntzen, J. W., Baird, S. J. E., Bierne, N., Boughman, J., Brelsford, A., Buerkle, C. A., Buggs, R. \& Butlin, R. K. 2013: Hybridization and speciation. - J. Evol. Biol. 26(2): 229-246. https://doi. org/10.1111/j.1420-9101.2012.02599.x

Abe, J. \& Shimamoto, Y. 1989: Evolutionary aspects and species relationships. International Crop Network Series (IBPGR). Workshop, held at Wageningen, the Netherlands, 7-10 February 1989.

Agudelo-Jaramillo, S., Ochoa-Mũ noz, M. \& Zuluaga-Díaz, F. I. 2016: Principal Component Analysis for MixedQuantitative and Qualitative Data. - Medellin.

Andersen, N. S., Siegismund, H. R., Meyer, V. \& Jørgensen, R. B. 2005: Low level of gene flow from cultivated beets (Beta vulgaris L. ssp. vulgaris) into Danish populations of sea beet (Beta vulgaris L. ssp. maritima (L.) Arcangeli). - Molec. Ecol. 14(5): 1391-1405. https://doi.org/10.1111/j.1365-294X.2005.02490.x

Bartsch, D., Cuguen, J., Biancardi, E. \& Sweet, J. 2003: Environmental implications of gene flow from sugar beet to wild beet-current status and future research needs. - Environ. Biosafety Res. 2(2): 105-115. https://doi.org/10.1051/ebr:2003006 
Biancardi, E., Panella, L. W. \& McGrath, J. M. 2020: Beta maritima - The Origin of Beets, $2^{\circ}$ ed. Cham.

Böhm, J., Schipprack, W., Utz, H. F. \& Melchinger, A. E. 2017: Tapping the genetic diversity of landraces in allogamous crops with doubled haploid lines: a case study from European flint maize. - Theor. Appl. Genet. 130(5): 861-873. https://doi.org/10.1007/s00122-017-2856-x.

Boudry, P., Wieber, R., Saumitou-Laprade, P., Pillen, K., Van Dijk, H. \& Jung, C. 1994: Identification of RFLP markers closely linked to the bolting gene B and their significance for the study of the annual habit in beets (Beta vulgaris L.). - Theor. Appl. Genet. 88(6-7): 852-858. https://doi.org/10.1007/BF01253996

—, - McCombie, H. \& Van Dijk, H. 2002: Vernalization requirement of wild beet Beta vulgaris ssp. maritima: among population variation and its adaptive significance. - J. Ecol. 90(4): 693703. https://www.jstor.org/stable/3072271

Buttler, K. P. 1977: Variation in wild populations of annual beet (Beta, Chenopodiaceae). - Pl. Syst. Evol. 128(1-2): 123-136. https://doi.org/10.1007/BF00985176

Castro, S., Romeiras, M. M., Castro, M., Duarte, M. C. \& Loureiro, J. 2013: Hidden diversity in wild Beta taxa from Portugal: insights from genome size and ploidy level estimations using flow cytometry. - Pl. Sci. 207: 72-78. https://doi.org/10.1016/j.plantsci.2013.02.012

Cholastova, T. \& Knotova, D. 2012: Using morphological and microsatellite (SSR) markers to assess the genetic diversity in Alfalfa (Medicago sativa L.). - World Acad. Sci. Engin. Technol. 69: 856-862.

El Bahloul, Y. 2007: Détermination de la distribution des principales espèces sauvages du genre Beta au Maroc, Caractérisation morphologique et analyse moléculaire de leur diversité génétique. - Doctoral dissertation. Faculté de sciences, Département de Biologie. Faculté Universitaire Notre-Dame de la Paix, Belgique.

Fan, H., Zhang, Y., Sun, H., Liu, J., Wang, Y., Wang, X., Li, D., Yu, J. \& Han, C. 2015: Transcriptome analysis of Beta macrocarpa and identification of differentially expressed transcripts in response to Beet necrotic yellow vein virus infection. - PLoS One 10(7): p.e0132277. https://doi.org/10.1371/journal.pone.0132277

Flowers, T. J., Troke, P. F. \& Yeo, A. R. 1977: The mechanism of salt tolerance in halophytes. - Ann. Rev. Pl. Physiol. 28(1): 89-121. https://doi.org/10.1146/annurev.pp.28.060177.000513

Galbraith, D. W., Harkins, K. R., Maddox, J. M., Ayres, N. M., Sharma, D. P. \& Firoozabady, E. 1983: Rapid flow cytometric analysis of the cell cycle in intact plant tissues. - Science 220(4601): 1049-1051. 10.1126/science.220.4601.1049

Hansche, P. E., Hesse, C. O. \& Beres, V. 1972: Estimates of genetic and environmental effects on several traits in peach. - J. Amer. Soc. Hortic. Sci. 97: 76-79.

Hellier, B. C., Richardson, K., El Bahloul Y. \& Qariouh, N. 2013: Status Report on the Beta Collection at the Western Regional Plant Introduction Station (WRPIS) to the Sugar beet Crop Germplasm Committee. - Barbara Hellier (Curator), Sugar Beet CGC Meeting February 27.

Hessini, K., Lachaâl, M. \& Soltani, A. 2005: Physiological response to sodium chloride of wild Swiss chard. - J. Pl. Nutr. 28(5): 877-888. https://doi.org/10.1081/PLN-200055567

Hôft, N., Dally, N., Hasler, M. \& Jung, C. 2018: Haplotype variation of flowering time genes of sugar beet and its wild relatives and the impact on life cycle regimes - Frontiers Pl Sci. 8: 2211. https://doi.org/10.3389/fpls.2017.02211

Iamonico, D. 2019: Remarks on the nomenclature of Betoideae (Chenopodiaceae/Amaranthaceae sensu APGIV). - Phytotaxa 400(3): 145-164. https://doi.org/10.11646/phytotaxa.400.3

IPGRI, 1991: Descriptors for Beta (Beta ssp). International Plant Genetic Resources Institute. Rome. 
Kadereit, G., Hohmann, S. \& Kadereit, J. W. 2006: A synopsis of Chenopodiaceae subfam. Betoideae and notes on the taxonomy of Beta. - Willdenowia 36(Special Issue): 9-12. https://doi.org/10.3372/wi.36.36101

Kiers, H.A.L. 1989: Three-way methods for the analysis of qualitative and quantitative two-way data. - Leiden.

Kishima, Y., Mikami, T., Hirai, A., Sugiura, M. \& Kinoshita, T. 1987: Beta chloroplast genomes: analysis of fraction I protein and chloroplast DNA variation. - Theor. Appl. Genet. 73(3): 330336. https://doi.org/10.1007/BF00262497

Lange, W. \& De Bock, T. S. 1989: The diploidised meiosis of tetraploid Beta macrocarpa and its possible application in breeding sugar beet. - Pl. Breeding. 103(3): 196-206. https://doi.org/10.1111/j.1439-0523.1989.tb00371.x

Letschert, J. P. W. 1993: Beta Section Beta: Biogeographical Patterns of Variation and Taxonomy. PhD dissertation, - Wageningen Agric. Univ. Pap. 93: 1-137.

Leys, M., Petit, E. J., El-Bahloul, Y., Liso, C., Fournet, S. \& Arnaud, J. F. 2014: Spatial genetic structure in Beta vulgaris subsp. maritima and Beta macrocarpa reveals the effect of contrasting mating system, influence of marine currents, and footprints of postglacial recolonization routes. - Ecol. Evol. 4(10): 1828-1852. https://doi.org/10.1002/ece3.1061

Limin, A. E. \& Fowler, D. B. 2006: Low-temperature tolerance and genetic potential in wheat (Triticum aestivum L.): response to photoperiod, vernalization, and plant development. Planta 224(2): 360-366. https://doi.org/10.1007/s00425-006-0219-y

McFarlane, J. S. 1975: Naturally occurring hybrids between sugar beet and Beta macrocarpa in the Imperial Valley of California. - J. Amer. Soc. Sugar Beet Technol. 18: 245-251.

McGrath, J. M. \& Panella, L. 2018: Sugar beet breeding. - Pl. Breeding Rev. 42: 167-218. https://doi.org/10.1002/9781119521358.ch5

Michael, T. E. B., Faigenboim, A., Shemesh-Mayer, E., Forer, I., Gershberg, C., Shafran, H., Rabinowitch, H. D. \& Kamenetsky-Goldstein, R. 2020: Crosstalk in the darkness: bulb vernalization activates meristem transition via circadian rhythm and photoperiodic pathway. BMC Pl. Biol. 20(1): 1-16. https://doi.org/10.1186/s12870-020-2269-x

Nagamine, T., Catty, J. P. \& Ford-Lloyd, B. V. 1989: Phenotypic polymorphism and allele differentiation of isozymes in fodder beet, multigerm sugar beet and monogerm sugar beet. - Theor. Appl. Genet. 77(5): 711-720. https://doi.org/10.1007/BF00261249

Nghiem, C. Q., Griffin, R. A., Harbard, J. L., Harwood, C. E., Le, S., Nguyen, K. D. \& Van Pham, B. 2018: Reduced fertility in triploids of Acacia auriculiformis and its hybrid with $A$. mangium. - Euphytica 214(4): 284-287. https://doi.org/10.1007/s10681-018-2157-8

Peltier, C., Klein, E., Hleibieh, K., D’Alonzo, M., Hammann, P., Bouzoubaa, S., Ratti, C. \& Gilmer, D. 2012: Beet necrotic yellow vein virus subgenomic RNA3 is a cleavage product leading to stable non-coding RNA required for long-distance movement. - J. General Virol. 93(5): 10931102. https://doi.org/10.1099/vir.0.039685-0

Pottier-Alapetite, G. 1979: Daucus - Pp. 615-621 in : Flore de la Tunisie, 1. - Tunis.

Reeves, P. A., He, Y., Schmitz, R. J., Amasino, R. M., Panella, L. W. \& Richards, C. M. 2007: Evolutionary conservation of the FLOWERING LOCUS C-mediated vernalization response: evidence from the sugar beet (Beta vulgaris). - Genetics 176(1): 295-307. https://doi.org/10.1534/genetics.106.069336

Rhoné, B., Remoué, C., Galic, N., Goldringer, I. \& Bonnin, I. 2008: Insight into the genetic basis of climatic adaptation in experimentally evolving wheat populations. - Molec. Ecol. 17(3): 930943. https://doi.org/10.1111/j.1365-294X.2007.03619.x

Scott, R. K. \& Longden, P. C. 1970: Pollen release by diploid and tetraploid sugar-beet plants. - Ann. Appl. Biol. 66(1): 129-135. https://doi.org/10.1111/j.1744-7348.1970.tb04610.x 
Slama, I., Jdey, A., Rouached, A., Talbi, O., Debez, A., Ghnaya, T., Limami, M. A. \& Abdelly, C. 2016: Comparative responses to water deficit stress and subsequent recovery in the cultivated beet Beta vulgaris and its wild relative B. macrocarpa. - Crop Pasture Sci. 67(5): 553-562. https://doi.org/10.1071/CP15145

Soltis, P. S., Marchant, D. B., Van de Peer, Y. \& Soltis, D. E. 2015: Polyploidy and genome evolution in plants. - Curr. Opin. Genet. Developm. 35: 119-125. https://doi.org/10.1016/j. gde.2015.11.003

Trueblood, C. E., Ranney, T. G., Lynch, N. P., Neal, J. C. \&, Olsen, R. T. 2010: Evaluating fertility of triploid clones of Hypericum androsaemum L. for use as non-invasive landscape plants. HortScience 45(7): 1026-1028. https://doi.org/10.21273/HORTSCI.45.7.1026

Uotila, P. 2011: Chenopodiaceae (pro parte majore), Juglandaceae, Loranthaceae, Molluginaceae, Moraceae, Nyctaginaceae, Phytolaccaceae, Santalaceae, Typhaceae. In Euro+ Med Plantbase-the information resource for Euro-Mediterranean plant diversity. Euro+ med plantbase.

http://ww2.bgbm.org/EuroPlusMed/PTaxonDetail.asp?NameId=7721045\&PTRefFk=730000

0 [Last accessed 8/11/2021]

Van Dijk, H. \& Desplanque B. 1999: European Beta: crops and their wild and weedy relatives. - Pp. 257-270 in: Van Raamsdonk, L. W. D. \& Den Nijs, J. C. M. (eds), Plant Evolution in ManMade Habitats. - Amsterdam. https://doi.org/10.1016/S1146-609X(97)80080-X

—, Boudry, P., McCombre, H. \& Vernet, P. 1997: Flowering time in wild beet (Beta vulgaris ssp. maritima) along a latitudinal cline. - Acta Oecol. 18(1): 47-60.

Villain, S. 2007: Histoire évolutive de la section Beta, : mise en évidence des phénomènes d'hybridation et de spéciation au sein de la section dans le bassin méditerranéen. - PhD. Université des Sciences et Technologies de Lille.

Addresses of the authors:

Siham Oumouss ${ }^{1,2}$, Ghizlane Tobi ${ }^{1}$, Ilham Rahmouni ${ }^{1}$, Hikmat Tahiri ${ }^{2}$ \& Yasmina El Bahloul ${ }^{*}$,

${ }^{1}$ National Institute of Agronomic Research (INRA-Morocco), Genetic Resources and Plant Breeding Unit, CRRA-Rabat, BP 6570, 10101 Rabat Institute, Morocco. Emails: siham.oumouss@gmail.com,_tobighizlane@gmail.com, ilham.rahmouni@gmail.com, yasmina.elbahloul@yahoo.com

${ }^{2}$ Mohammed V University, Department of Biology, Laboratory of Botany and Valorization of Plant and Fungal Resources, Faculty of Sciences Rabat, B.P. 1014 RP, Rabat, Morocco. E-mail: tahiri47@gmail.com

${ }^{*}$ Corresponding author 